\title{
Explaining the increase in coronary heart disease mortality in Syria between 1996 and 2006
}

\author{
Samer Rastam ${ }^{1,5^{*}}$, Radwan AL Ali', Wasim Maziakk ${ }^{1,2}$, Fawaz Mzayek ${ }^{1,3}$, Fouad M Fouad', Martin O'Flaherty ${ }^{4}$ and \\ Simon Capewell ${ }^{4}$
}

\begin{abstract}
Background: Despite advances made in treating coronary heart disease (CHD), mortality due to CHD in Syria has been increasing for the past two decades. This study aims to assess CHD mortality trends in Syria between 1996 and 2006 and to investigate the main factors associated with them.

Methods: The IMPACT model was used to analyze CHD mortality trends in Syria based on numbers of CHD patients, utilization of specific treatments, trends in major cardiovascular risk factors in apparently healthy persons and CHD patients. Data sources for the IMPACT model included official statistics, published and unpublished surveys, data from neighboring countries, expert opinions, and randomized trials and meta-analyses.

Results: Between 1996 and 2006, CHD mortality rate in Syria increased by 64\%, which translates into 6370 excess CHD deaths in 2006 as compared to the number expected had the 1996 baseline rate held constant. Using the IMPACT model, it was estimated that increases in cardiovascular risk factors could explain approximately 5140 (81\%) of the CHD deaths, while some 2145 deaths were prevented or postponed by medical and surgical treatments for CHD.

Conclusion: Most of the recent increase in CHD mortality in Syria is attributable to increases in major cardiovascular risk factors. Treatments for CHD were able to prevent about a quarter of excess CHD deaths, despite suboptimal implementation. These findings stress the importance of population-based primary prevention strategies targeting major risk factors for CHD, as well as policies aimed at improving access and adherence to modern treatments of $\mathrm{CHD}$.
\end{abstract}

Keywords: Coronary heart disease, Mortality, Modelling

\section{Background}

Coronary heart disease (CHD) is projected to be the leading global cause of death and disability by 2020 [1]. Most of the global burden from cardiovascular disease (CVD) morbidity and mortality is taking place in the developing countries, and CVD has already overtaken infectious diseases as the main threat to public health [2-5]. In the Eastern Mediterranean Region (EMR), CVD mortality accounts for almost a third of all deaths, and is mainly due to CHD [2]. According to available evidence, mortality rates from $\mathrm{CHD}$ are on the rise for most countries of the EMR [6,7]. In Syria, one of the low-middle

\footnotetext{
* Correspondence: mrastam@gmail.com

'Syrian Centre for Tobacco Studies, Aleppo, Syria

${ }^{5}$ Syrian Center for Tobacco Studies Syrian Society against Cancer building, St. Aleppo, Shihan, Syria

Full list of author information is available at the end of the article
}

income countries of the EMR (population $\approx 20$ million; 2006), CHD is the main cause of CVD mortality, and together with stroke accounts for about half of all-cause mortality [8]. One of the notable patterns of CHD morbidity and mortality in the EMR compared to developed countries is their earlier onset, which translates into loss of productive years and more strain on the already burdened livelihood of poor communities [9].

Designing effective interventions to reduce CHD burden in developing countries needs to be guided by local data to identify main risk factors driving CHD incidence, and the most effective approach to reduce CHD burden considering the resources available [10]. Unfortunately, for most of the developing world, including countries of the EMR, very few reliable data exist about the main drivers of CHD mortality in terms of treatment and risk

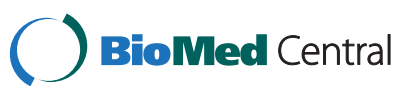


factors. As part of a new project funded by the EU (Medchamps: Mediterranean Studies of Cardiovascular disease and Hyperglycaemia: Analytical Modelling of Population Socio-economic transitions), we started collecting and analysing such data for several countries in the Mediterranean region (Syria, Tunisia, Palestinian authority, and Turkey).

According to WHO estimates, CHD mortality in Syria showed increasing trends during the past two decades $[11,12]$. This study aims to explain these trends between 1996 and 2006, and to examine factors associated with them, using a validated modelling approach.

\section{Methods}

The IMPACT mortality model was adopted in this study to quantify the effects on CHD mortality attributable to changes in each population risk factors and treatment modalities between 1996 and 2006. The IMPACT model was previously validated in developed and developing countries such as New Zealand, China and Scotland [1315]. Briefly, the IMPACT model is used to estimate the number of coronary heart disease (CHD) deaths prevented by each specific cardiac intervention, or risk factor decline or vice versa. The comparison between the increase of treatment for CHD disease and cardiovascular mortality represents another approach applied to obtain a more precise estimate of the role of the reduction of each risk factor. In this study, adults' data including: (1) number of CHD patients, (2) use of specific medical and surgical treatments, (3) effectiveness of specific treatments for CHD, (4) population trends of major cardiovascular risk factors (smoking, total cholesterol, hypertension, obesity, and diabetes), were incorporated in the model. Details are shown in Additional file 1.

\section{Data sources and assessment}

Syrian data on risk factors and current practices for treating CHD patients were identified through extensive search of published and unpublished data and complemented with specifically designed surveys. All data sources were critically appraised by Syrian Centre for Tobacco Studies (SCTS) and Medchamps teams and the results of this process are presented in the Additional file 1 .

Data used to populate the model included: a) population statistics and CHD related mortality, b) patient numbers in specific CHD groups (Myocardial Infarction (MI), Congestive Heart Failure (CHF), Chronic Angina Pectoris (AP), c) use of specific medical and surgical treatments for $\mathrm{CHD}$, and $\mathrm{d}$ ) population trends in major cardiovascular risk factors. The main outcome of the model was number of deaths prevented or postponed (DPP) due to changes in risk factors or the application of certain treatments.

\section{Information on the population demographic changes}

Demographic information for Syria between 1996-2006 were obtained from the Syrian bureau of Statistics [16]. Numbers were comparable to the numbers provided by the U.N. department of economics and social affairs [17]. Numbers of CHD related deaths for both years were obtained from the WHO Global Health Observatory [11]. These numbers were cross-validated with data provided by the Aleppo Household Survey (AHS), which was conducted in 2004, and in which mortality estimates were calculated from participant-reported deaths among their adult household members ( $>20$ years) during the five years preceding the time of the survey. [18]. Because mortality data for Syria are not available for every year, mortality rates for 1996 were estimated from data of 1985 and 2004, which are the closest available data points to 1996 using the geometric mean of the agespecific death rates [19]. These data were obtained from the WHO Statistical Information System $[11,12]$.

\section{Data on population risk factors' trends}

Data for the year 2006 were obtained from two epidemiological studies. The first one was the STEPwise survey conducted by WHO in the rural and urban areas of Syria in 2003 with people up to 65 years were included; and in which a nationally representative sample of 9184 participants were surveyed [20]. The second one was the Aleppo Diabetes Survey (ADS) - conducted in 2006 -in which a representative sample of 1168 aged $\geq 25$ years from the city of Aleppo ( $2^{\text {nd }}$ largest city with population $\approx 2.5$ million) were surveyed [21]. Syrian data for the year 1996 were not available; therefore, they were extrapolated from the Palestinian Authority data, because those data were the most complete and standardized ones among neighbouring countries and because of the ethnic and cultural similarities of the two populations.

\section{Data on CHD hospital admissions and (in-hospital) treatment}

Because no valid information was available on CHD hospitalization and treatment, the SCTS has conducted a survey in 2009 specifically for this project. The survey covered 6 major hospitals. Three of these hospitals provide cardiac care in the Aleppo province, and the other 3 were general hospitals.

\section{Data on treatment use for CHD in the community}

Data for 2008 were obtained from an outpatient survey conducted by SCTS in 2009 using a random sample of five health centres. Information on treatment uptake in the community was verified with the help of experts' opinion using a special questionnaire about treatment of CHD, assuming that treatment use did not change significantly between 2006 and 2008 . 


\section{Data on efficacy of therapeutic interventions}

Data were based on the results of recent meta-analyses and randomised controlled trials [22-52]. The Mant and Hicks approach was used to correct for polypharmacy in individual patients [53].

Population and mortality data were obtained from openly available sources; data on current risk factor profile and treatment uptakes were obtained from surveys conducted by SCTS; while data on risk factor profile for 1996 with permission to be used was obtained with from Institute of Community and Public Health, Birzeit University.

\section{Assessment of trends in CHD deaths (1996-2006) and the relative contribution of treatment and risk factors}

First, the number of CHD deaths expected in 2006 was calculated by indirect age standardisation based on the assumption that 1996 mortality rates had persisted unchanged until 2006. The number of CHD deaths actually observed in 2006 was then subtracted. The difference between the two represents the rise in CHD deaths that the model needed to explain.

The number of additional deaths attributable to changes in cardiovascular risk factors was estimated using regression coefficients ( $\beta$ ) to quantify the population mortality impact of changes in risk factors measured as continuous variables (blood pressure, total cholesterol and BMI). For categorical risk factors, including diabetes, physical inactivity and smoking, the population attributable risk fraction was used based on the standard formula:

$$
\text { PAR }=\frac{\text { Prevalence } 0.5 e m x(\text { Relative Risk }-1)}{[\text { Prevalence } \mathrm{x}(\text { Relative Risk }-1)+1]}
$$

To assess the effect of the treatment type on CHD mortality, the model needed to include all medical and surgical treatments in 1996 (the base year) and 2006 (the final year). However, detailed information on treatment modalities was not available for the year 1996. The data included in the model for 1996 were therefore estimated based on feedback from the ten leading local cardiologists in Aleppo, who treated CHD patients in hospitals and the community at that time using a short survey with standardized questions commonly used in the IMPACT model.

The mortality reduction attributable to each treatment type was calculated as the number of patients in each age and sex group multiplied by three factors: 1) the baseline, age-specific case fatality rate observed in that group, 2) the relative mortality reduction reported in published meta-analyses [22-52], and 3) the proportion receiving that specific treatment (Additional file 1). Case-fatality data were obtained from large, unselected, population- based patient cohorts [54]. Survival benefit over a oneyear time interval was used for all treatments.

Potential overlaps between different groups of patients were identified and appropriate adjustments were made. Patient group calculations and all other assumptions are detailed in the Additional file 1. Adherence (defined as the proportion of treated patients actually taking therapeutically effective levels of the prescribed medication) was assumed to be $100 \%$ among hospital patients, $70 \%$ among all symptomatic community patients, and 50\% among asymptomatic community patients, based on the literature. [55-57]

\section{Sensitivity analysis}

Because of the uncertainties surrounding some of the values used in the modelling, multi-way sensitivity analysis using Brigg's analysis of extremes was used. [58]

\section{Results}

Between 1996 and 2006, CHD mortality rates in Syria increased by $64 \%$ (from 129 to 212 per 100,000 personyears; $58 \%$ in men and $75 \%$ in women). This resulted in 6370 additional CHD deaths in 2006 compared to the number expected had the 1996 mortality rates persisted. Mortality increases were seen in men and women in all age groups (Table 1).

\section{Major CHD risk factors}

Of the 6370 excess CHD deaths in 2006, 5140 (minimum 3165 and maximum 7705) can be explained by changes of major cardiovascular risk factors between 1996 and 2006. This represents $80.7 \%$ of the observed increase in CHD- mortality.

Changes in risk factors were complex: $0.31 \mathrm{mmol} / \mathrm{L}$ rise in total cholesterol $(0.22 \mathrm{mmol} / \mathrm{L}$ in men and 0.39 $\mathrm{mmol} / \mathrm{L}$ in women), $9 \mathrm{mmHg}$ rise in mean systolic blood pressure (SBP) $(6 \mathrm{mmHg}$ in men and $11 \mathrm{mmHg}$ in women), $4.7 \%$ rise in diabetes prevalence $(4.1 \%$ in men, $5.3 \%$ in women), and a 1.8 units rise in BMI (1.5 in men, 2.2 in women).

Approximately 52\% (2680, minimum 1620 and maximum 4110) of the excess deaths that were explained by changes in cardiovascular risk factors were attributable to increases in SBP; $19 \%(1000,640$ and 1460) to increases in total cholesterol; 15\% (770, 490 and 1105) to increases in diabetes prevalence; $9 \%(470,270$ and $710)$ to increases in BMI; and $4 \%(225,145$ and 320$)$ to increases in smoking prevalence. (Table 2).

\section{Medical and surgical treatments}

Medical and surgical treatments together prevented or postponed approximately 2145 deaths in 2006 (minimum 1135, maximum 5475). In the absence of these treatments, there would have been approximately 2145 
Table 1 Population sizes and death rates from CHD in Syria, 1996 and 2006

\begin{tabular}{|c|c|c|c|c|c|c|c|}
\hline & & & Men & & & & \\
\hline Age groups & $25-34$ & $35-44$ & $45-54$ & $55-64$ & $65-74$ & +75 & +25 \\
\hline Population in 1996 & 1063649 & 652453 & 381580 & 269255 & 171321 & 62074 & 2600332 \\
\hline Population in 2006 & 1478983 & 1053893 & 636889 & 351702 & 213778 & 107432 & 3842677 \\
\hline Deaths in 1996 (number) & 379 & 542 & 522 & 743 & 1423 & 583 & 4191 \\
\hline Deaths in 2006 (number) & 955 & 1573 & 1263 & 1327 & 3000 & 1674 & 9793 \\
\hline Death rates per 100,000 in 1996 & 36 & 83 & 137 & 276 & 831 & 939 & 161 \\
\hline Death rates per 100,000 in 2006 & 65 & 149 & 198 & 377 & 1403 & 1558 & 255 \\
\hline \multirow[t]{2}{*}{$\%$ Change (crude) } & $81 \%$ & $80 \%$ & $45 \%$ & $37 \%$ & $69 \%$ & $66 \%$ & $58 \%$ \\
\hline & \multicolumn{6}{|c|}{ Women } & \\
\hline Age groups & $25-34$ & $35-44$ & $45-54$ & $55-64$ & $65-74$ & +75 & +25 \\
\hline Population in 1996 & 1019177 & 634984 & 381124 & 271637 & 168367 & 66709 & 2541998 \\
\hline Population in 2006 & 1432147 & 1016763 & 627629 & 363840 & 234341 & 127094 & 3801814 \\
\hline Deaths in 1996 (number) & 145 & 195 & 256 & 314 & 911 & 642 & 2463 \\
\hline Deaths in 2006 (number) & 315 & 517 & 680 & 604 & 2268 & 2061 & 6445 \\
\hline Death rates per 100,000 in 1996 & 14 & 31 & 67 & 116 & 541 & 963 & 97 \\
\hline Death rates per 100,000 in 2006 & 22 & 51 & 108 & 166 & 968 & 1622 & 170 \\
\hline$\%$ Change (crude) & $55 \%$ & $66 \%$ & $61 \%$ & $44 \%$ & $79 \%$ & $68 \%$ & $75 \%$ \\
\hline
\end{tabular}

additional CHD deaths. The total treatment effect represented a $34 \%$ reduction of the overall CHD mortality (minimum estimate $18 \%$ and maximum $86 \%$, Figure 1). Treatment of angina pectoris in the community explained over $38 \%$ of reduction in CHD deaths (805, minimum 665 and maximum 2125), most being attributable to aspirin and statin therapies (Table 3).

Secondary prevention following acute myocardial infarction explained over $17 \%$ of reduction in CHD deaths (370), mostly due to beta blockers and aspirin). Approximately $15 \%$ (330) of deaths were prevented by heart failure treatments in the community (particularly spironolactone), and 14\% (290) were attributable to initial treatments for acute myocardial infarction (especially thrombolysis and aspirin). However, the mortality reductions attributable to coronary surgery and statins for primary prevention were modest $(4.7 \%$ and $2.3 \%$ respectively, Table 3).

\section{Model validation and fit}

The model explained approximately $81 \%$ of the total CHD mortality increase in the Syrian population between 1996 and 2006. The remaining 19\% was unexplained and might reflect data limitations or other unmeasured factors such as physical inactivity, stress dietary factors.

It is perfectly reasonable to instead present the total deaths to explain as 8,515 deaths $(6,370+2,145)$ deaths. In which case the 5140 deaths attributable to risk factor changes would represent approximately $60 \%$ of the total mortality increase.
The relative contributions of the risk factors studied remained relatively consistent, irrespective of whether the best, the minimum, or the maximum DPP estimates were used.

\section{Discussion}

Coronary heart disease mortality increased in Syria by over 60\% between 1996 and 2006. These trends resembled those in other developing countries such as China (using the same IMPACT model), as well as India $[14,59]$. Much of this mortality rise can be attributed to adverse trends in major risk factors such as blood pressure, cholesterol and diabetes. This is the first study to examine factors underlying the rise of CHD mortality in Syria. It, therefore, provides important and timely information that could guide national efforts to reduce the burden of CHD in Syria. It also can potentially provide useful information for other comparable Arab countries in the EMR.

The largest fractions of CHD excess mortality paralleled the increases in major CHD risk factors, with almost $60 \%$ of the mortality increase being attributable to elevated blood pressure and total cholesterol. These trends are consistent with the overall shift in Arab societies towards urbanization, modernization and lifestyles characterized by unhealthy diet and inactivity. Available data from Syria and other Arab countries in the EMR consistently show dramatic increases in obesity and diabetes, whereby overweight and obesity among adults in the EMR range from $25 \%$ to a staggering $82 \%$ [60]. In Syria obesity now affects over half $(52 \%)$ of adult women 
Table 2 Deaths attributable to population risk factor changes in Syria between 1996 and 2006

\begin{tabular}{|c|c|c|c|c|c|c|c|c|c|}
\hline \multirow[t]{2}{*}{ RISK FACTORS* } & \multicolumn{2}{|c|}{$\begin{array}{c}\text { Risk factor levels } \\
19962006\end{array}$} & \multirow{2}{*}{$\begin{array}{c}\text { Relative } \\
\text { Change (\%) in risk } \\
\text { factor } 1996-2006\end{array}$} & \multirow{2}{*}{\multicolumn{2}{|c|}{$\begin{array}{c}\text { Relative Risk (RR }{ }^{1} \text { ) } \\
\text { (or } \beta \text { eta Coefficient) }^{2}\end{array}$}} & \multicolumn{4}{|c|}{ Increase in Deaths } \\
\hline & & & & & & $\begin{array}{c}\text { Best } \\
\text { Estimate }\end{array}$ & $\begin{array}{l}\text { Minimum } \\
\text { estimate }\end{array}$ & $\begin{array}{l}\text { Maximum } \\
\text { estimate }\end{array}$ & $\begin{array}{l}\text { Proportion of } \\
\text { overall deaths }\end{array}$ \\
\hline Cholesterol $\mathrm{mmol} / \mathrm{l}$ & & & & & & 1000 & 635 & 1460 & $15.7 \%$ \\
\hline Cholesterol (men) & 5.01 & 5.23 & 4.5 & & 0.65 & & & & \\
\hline Cholesterol (women) & 5.07 & 5.46 & 7.6 & & 0.65 & & & & \\
\hline \multirow[t]{3}{*}{ Smoking ( \%) } & & & & $1,60(1$ & -9 cig/d); & 225 & 145 & 320 & $3.5 \%$ \\
\hline & & & & $1.80(10$ & -19 cig/d); & & & & \\
\hline & & & & $2.10(>$ & $20 \mathrm{cig} / \mathrm{d})$ & & & & \\
\hline (\% men smoking) & 55.3 & 58.6 & 6.0 & & & & & & \\
\hline (\% women smoking) & 10.0 & 15.0 & 49.4 & & & & & & \\
\hline \multicolumn{3}{|l|}{ BMI $\mathrm{Kg} / \mathrm{m}^{2}$} & & & & 470 & 270 & 710 & $7.3 \%$ \\
\hline BMI (men) & 26.75 & 28.26 & 5.6 & & 0.02 & & & & \\
\hline BMI (women) & 29.08 & 31.24 & 7.4 & $\beta$ & 0.02 & & & & \\
\hline \multicolumn{3}{|l|}{ Diabetes (\%) } & & & & 770 & 490 & 1105 & $12.0 \%$ \\
\hline Diabetes (men) & 7.4 & 11.5 & 55.6 & & 2 & & & & \\
\hline Diabetes (women) & 10.1 & 15.5 & 52.6 & & 2 & & & & \\
\hline \multicolumn{4}{|c|}{ Population systolic BP mm/Hg } & & & 2680 & 1620 & 4110 & $42.1 \%$ \\
\hline Population BP (men) & 125.6 & 131.8 & 4.9 & $\beta$ & 0.053 & & & & \\
\hline Population BP (women) & 118.7 & 129.9 & 9.5 & $\beta$ & 0.053 & & & & \\
\hline Physical inactivity & - & - & - & & - & - & - & - & - \\
\hline \multicolumn{6}{|c|}{ Estimated total risk factor effects } & 5140 & 3155 & 7705 & $80.7 \%$ \\
\hline
\end{tabular}

${ }^{*}$ Numbers of increases in deaths were rounded to nearest 0 or 5 .

[21]. These unfavourable trends contribute to an adverse cardiovascular risk factors' profile, including a higher prevalence of diabetes and elevated cholesterol levels, as is seen in this study. The common behavioural roots underlying CVD risk increases in the Syrian population potentially highlight opportunities to reduce mortality rates through population-based interventions promoting healthy eating and active lifestyles. This also emphasizes the need for a national strategy to address noncommunicable diseases in Syria using a combination of health promotion, fiscal measures, market controls and community involvement to encourage healthy lifestyles [61]. The contribution of smoking to increased CHD mortality was modest, as smoking prevalence hardly changed between 1996 and 2006.

This reflects a lack of effective tobacco control policies in Syria, and a complex political situation, where the government agency responsible for tobacco production and sale is much more powerful that the tobacco control unit at the ministry of health.

Modern medical treatments together prevented or postponed 2145 excess deaths in Syria in 2006, equivalent to about one fourth of the total CHD mortality. The biggest contributions came from long-term management of CHD, mainly for secondary prevention, angina, and heart failure. The contributions from surgery and angioplasty were small, accounting for $4 \%$ of the mortality reduction. Our previous research in Syria showed that in spite of high prevalence of CHD risk factors, such as hypertension, awareness and, consequently, treatment and control of such conditions tended to be low [21]. For example, our research has shown that about $40.6 \%$ of population aged 18-65 years had hypertension, only $11.8 \%$ of them were aware of it, and only $8.6 \%$ were under treatment [8]. For diabetes, which affects $15.6 \%$ of population aged 25 years and above in Syria, only $11.2 \%$ were diagnosed, and only $16.7 \%$ of treated cases had their diabetes controlled adequately [62]. This modest contribution of medical treatment to reducing CHD mortality points out to a great potential for improvement in this area.

Treatment uptakes were moderate (60\%-90\%) for relatively cheap drugs, such as aspirin, thrombolytic therapy, and beta blockers, but much lower for more expensive surgical procedures. There was essentially no utilization of coronary artery bypass graft (CABG), primary transcutaneous coronary angioplasty (PTCA), rehabilitation, nor cardiac pulmonary resuscitation $(\mathrm{CPR})$ in the 


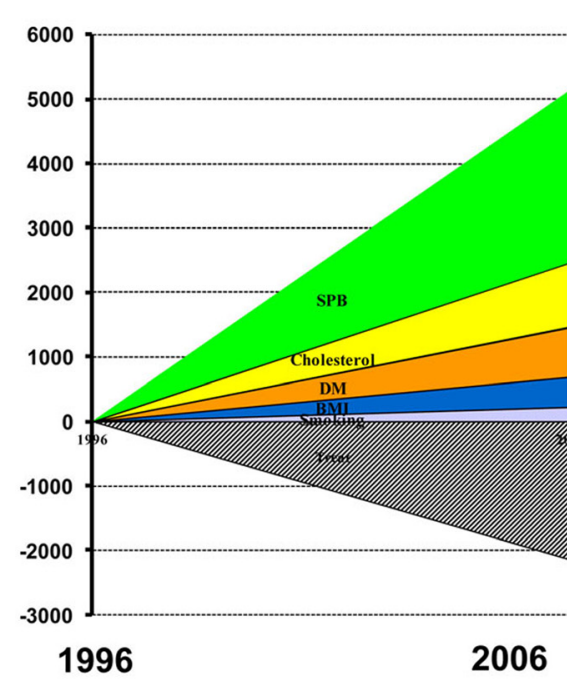

Observed increase in CHD death

Unexplained by model

All Risk Factor effects

Systolic Blood Pressure

Cholesterol

Diabetes

Obesity

Smoking:

\section{Total Treatments: 2145 fewer deaths}

Angina in community

2' prevention post MI or revasc.

Heart Failure in community

AMI therapies

Unstable angina

Heart Failure in hospitals

Hypertension therapies

Statins for 1' prevention

\section{$6370(100 \%)$}

(19\%)

5140

$2680(52 \%)$

$1000(19 \%)$

$770(15 \%)$

$470 \quad(9 \%)$

$225(4 \%)$

805

435

330

290

150

85

45

5

Figure 1 Coronary heart disease deaths prevented or postponed by treatment and risk factors changes in the Syrian population between 1996 and 2006.

community. In our study, surgical procedures had a very limited role in avoiding $\mathrm{CHD}$ deaths, resulting in approximately 100 fewer deaths $(\approx 5 \%$ of total treatment benefit). This small role may reflect the effects of the high cost of these procedures, the lack of access to specialized care for the general population, the limited availability of expertise and facilities needed to perform such procedures and the underdevelopment of the private and public health insurance sectors--a situation similar to that found in other developing countries, such as China [14]. This contrasts with the higher uptake in developed countries where, for instance, community resuscitation (i.e. out of health care facilities) reached $48 \%$ in England and Wales [63], and 50\% in New Zealand [13].

The IMPACT modelling in this study used a comprehensive approach, synthesizing data about all major risk factors and all standard treatment options used in the Syrian population between 1996 and 2006. However, this approach also has some limitations. The data used were of variable completeness and quality. We critically appraised the available data to ensure adequate quality for our modeling. For example, we did not rely on national death registry data for causes of death because these were incomplete and of questionable quality, instead, preferring mortality data from WHO estimates $[11,12]$. In addition, when data were not available, we used explicit assumptions including data from a comparable neighboring (Palestinian) population.

It is also perfectly reasonable to present the total deaths to explain as 8,515 deaths $(6,370+2,145)$. In which case the 5140 deaths attributable to risk factor changes would represent approximately $60 \%$ of the total mortality increase.

Lag times were not formally considered in the model. However, increasing evidence suggests that substantial mortality increases or falls may occur within a few years of risk factor changes [64]. Furthermore, certain assumptions were needed to fill in the gaps for missing information. For example, for the small group aged 65-74 years where risk factor information was not available we had to make assumptions based on the risk factors levels in the nearest age groups. These assumptions are detailed in the Additional file 1 and were supported by local expert opinions and literature from the region. All were tested in the sensitivity analysis. However, none of these limitations are expected to influence the validity of our main results, as the IMPACT model used in this study was developed to deal with such data problems.

\section{Conclusions}

CHD mortality in Syria rose by about 60\% between 1996 and 2006. More than two-thirds of this rise was attributable to changes in major risk factors such as blood pressure and total cholesterol. Despite suboptimal use, CHD treatments prevented or delayed 2145 CHD deaths in 2006 compared to 1996 . These results emphasise the importance of advocating adequate, early, and continuous treatments for CHD within the community.

Risk factor changes in the general population are important drivers of the recent CHD mortality rises, and mainly reflect lifestyles characterised by unhealthy eating 
Table 3 Deaths prevented or postponed by medical and surgical treatments in Syria in 2006

\begin{tabular}{|c|c|c|c|c|c|c|}
\hline \multirow[t]{2}{*}{ TREATMENTS } & \multirow{2}{*}{$\begin{array}{l}\text { Patients } \\
\text { eligible }\end{array}$} & \multirow{2}{*}{$\begin{array}{l}\text { Treatment } \\
\text { uptake (\%) }\end{array}$} & \multicolumn{3}{|c|}{ CHD deaths prevented or postponed } & \multirow{2}{*}{$\begin{array}{c}\text { Proportion of overall deaths } \\
\text { Prevented or } \\
\text { postponed (\%) }\end{array}$} \\
\hline & & & $\begin{array}{c}\text { Best } \\
\text { Estimate }\end{array}$ & $\begin{array}{l}\text { Minimum } \\
\text { estimate }\end{array}$ & $\begin{array}{c}\text { Maximum } \\
\text { estimate }\end{array}$ & \\
\hline Acute myocardial infarction & 18002 & & 285 & 120 & 540 & $4.5 \%$ \\
\hline Hospital resuscitation & & 0.05 & 13 & 8 & 23 & $0.2 \%$ \\
\hline Aspirin alone & & 0.96 & 151 & 62 & 266 & $2.4 \%$ \\
\hline Thrombolytic alone & & 0.59 & 128 & 53 & 266 & $2.0 \%$ \\
\hline Beta blockers & & 0.82 & 29 & 12 & 59 & $0.5 \%$ \\
\hline ACE inhibitors & & 0.74 & 56 & 23 & 115 & $0.9 \%$ \\
\hline Treatments in 1996 subtracted & & & -92 & -37 & -191 & \\
\hline $\begin{array}{l}\text { Secondary Prevention } \\
\text { post infarction }\end{array}$ & 78976 & & 372 & 125 & 949 & $5.8 \%$ \\
\hline Aspirin & & 0.46 & 112 & 37 & 278 & $1.8 \%$ \\
\hline Beta blockers & & 0.47 & 125 & 41 & 310 & $2.0 \%$ \\
\hline ACE inhibitors & & 0.33 & 92 & 30 & 230 & $1.4 \%$ \\
\hline Statins & & 0.28 & 90 & 29 & 223 & $1.4 \%$ \\
\hline Warfarin & & 0.04 & 16 & 5 & 39 & $0.2 \%$ \\
\hline Rehabilitation & & 0.10 & 36 & 12 & 89 & $0.6 \%$ \\
\hline Treatments in 1996 subtracted & & & -97 & -29 & -219 & \\
\hline $\begin{array}{l}\text { Secondary Prevention post } \\
\text { revascularisation ( } 5 \text { years) }\end{array}$ & 106517 & & 65 & 22 & 164 & $1.0 \%$ \\
\hline Angina & & & 803 & 664 & 2124 & $12.6 \%$ \\
\hline CABG surgery (1997-2006) & 106517 & 0.10 & 97 & - & - & $1.5 \%$ \\
\hline Aspirin & 319974 & 0.44 & 511 & 168 & 1273 & $8.0 \%$ \\
\hline Statins & 319974 & 0.34 & 443 & 116 & 1322 & $6.9 \%$ \\
\hline Treatments in 1996 subtracted & & & -248 & -75 & -671 & \\
\hline Treatments for unstable angina & 22877 & & 150 & 92 & 403 & $2.3 \%$ \\
\hline $\begin{array}{l}\text { Heart Failure with Hospital } \\
\text { admission }\end{array}$ & 6927 & & 84 & 25 & 223 & $1.3 \%$ \\
\hline ACE inhibitors & & 0.57 & 41 & 11 & 122 & $0.6 \%$ \\
\hline Beta blockers & & 0.22 & 22 & 6 & 67 & $0.4 \%$ \\
\hline Spironolactone & & 0.49 & 64 & 21 & 160 & $1.0 \%$ \\
\hline Aspirin & & 0.80 & 55 & 18 & 135 & $0.9 \%$ \\
\hline Treatments in 1996 subtracted & & & -99 & -30 & -262 & \\
\hline Heart failure in the community & 52251 & & 332 & 104 & 854 & $5.2 \%$ \\
\hline ACE inhibitors & & & 112 & 29 & 327 & $1.8 \%$ \\
\hline Beta blockers & & & 108 & 35 & 269 & $1.7 \%$ \\
\hline Spironolactone & & & 226 & 74 & 563 & $3.6 \%$ \\
\hline Aspirin & & & 97 & 32 & 240 & $1.5 \%$ \\
\hline Treatments in 1996 subtracted & & & -211 & -66 & -546 & \\
\hline Hypertension Treatments & 863425 & & 45 & 8 & 311 & $0.7 \%$ \\
\hline Statins for Primary Prevention & 307295 & & 6 & 2 & 65 & $0.5 \%$ \\
\hline Total treatment effects* & & & 2145 & 1165 & 5630 & $33.7 \%$ \\
\hline
\end{tabular}

* Numbers of category totals of deaths prevented or postponed were rounded to nearest 0 or 5 , totals may therefore not always sum exactly. $A C E$, angiotensin-converting enzyme; $C A B G$, coronary artery bypass graft surgery. 
habits and physical inactivity. These should be the priority targets for national efforts to reduce cardiovascular morbidity and mortality. This will represent great challenges, because effective, population-based policies will require clear public health vision, multi-sectoral approaches, adequate resources and firm political commitment [64].

\section{Additional file}

\section{Additional file 1: The caption for the additional file is: Syria Impact} Model; Data Sources Assumptions and Risks.

\section{Competing interests}

The authors declare that they have no competing interest.

\section{Authors' contributions}

SR originated the research question, conducted the analyses, interpreted the findings, and wrote the first dart of the article. RA contributed to the acquisition of data, analysis and interpretation of findings, and drafting of the manuscript. WM contributed to the interpretation of the findings, assisted with the editing of the article and supervision of the study. FM assisted with the editing of the article. FMF contributed to the acquisition of data. MOF contributed to analysis and interpretation of findings. SC contributed to drafting of the manuscript, analysis, interpretation of findings, critical revision, and supervision of the study. All authors read and approved the final manuscript.

\section{Acknowledgements}

This work was supported by the European Commission research project (FP7-HEALTH-2007-B- 223075), and by the National Institute on Drug Abuse (R01 DA024876). MOF was also funded by the UK Medical Research Council.

\section{Author details}

${ }^{1}$ Syrian Centre for Tobacco Studies, Aleppo, Syria. ${ }^{2}$ Robert Stempel College of Public Health and Social Work, Florida International University, Miami, FL, USA. ${ }^{3}$ University of Memphis, School of Public Health, Division of Epidemiology and Biostatistics, Memphis, TN, USA. ${ }^{4}$ Department of Public Health and Policy, University of Liverpool, Liverpool, UK. ${ }^{5}$ Syrian Center for Tobacco Studies Syrian Society against Cancer building, St.Aleppo, Shihan, Syria.

Received: 16 January 2012 Accepted: 29 August 2012

Published: 9 September 2012

\section{References}

1. Murray CJ, Lopez AD: Mortality by cause for eight regions of the world: Global Burden of Disease Study. Lancet 1997, 349(9061):1269-1276.

2. World Health Organization: The global burden of disease: 2004 update. 2008.

3. World Health Organization: The World health report 2003: shaping the future. Geneva, Switzerland: WHO; 2003.

4. Reddy KS: Cardiovascular diseases in the developing countries: dimensions, determinants, dynamics and directions for public health action. Public Health Nutr 2002, 5(1A):231-237.

5. Lopez AD, Mathers CD, Ezzati M, Jamison DT, Murray CJ: Global and regional burden of disease and risk factors, 2001: systematic analysis of population health data. Lancet 2006, 367(9524):1747-1757.

6. Sarrafzadegan N, Oveisgharan S, Toghianifar N, Hosseini S, Rabiei K: Acute Myocardial Infarction in Isfahan, Iran: Hospitalization and 28th day case-fata;ity Rate. ARYA Atherosclerosis Journal 2009, 5(3):132-137. Fall.

7. EMRO: Cardiovascular Diseases - prevention and Control - EMRO technical paper Series 7, October. 1998 [http://www.emro.who.int/dsaf/dsa444.pdf].

8. Maziak W, Rastam S, Mzayek F, Ward KD, Eissenberg T, Keil U: Cardiovascular health among adults in Syria: a model from developing countries. Ann Epidemiol 2007, 17(9):713-720.

9. Reddy KS, Yusuf S: Emerging epidemic of cardiovascular disease in developing countries. Circulation 1998, 97(6):596-601.

10. Gaziano TA: Reducing the growing burden of cardiovascular disease in the developing world. Health Aff (Millwood) 2007, 26(1):13-24.
11. World Health Organization: WHO Global Health Observatory. 2004 [http:// apps.who.int/ghodata/].

12. World Health Organization: WHO Statistical Information System. 2006 [http:// www.who.int/whosis/mort/download/en/index.html].

13. Capewell S, Beaglehole R, Seddon M, McMurray J: Explanation for the decline in coronary heart disease mortality rates in Auckland, New Zealand, between 1982 and 1993. Circulation 2000, 102(13):1511-1516.

14. Critchley J, Liu J, Zhao D, Wei W, Capewell S: Explaining the increase in coronary heart disease mortality in Beijing between 1984 and 1999. Circulation 2004, 110(10):1236-1244

15. Capewell S, Morrison C, McMurray J: Contribution of modern cardiovascular treatment and risk factor changes to the decline in coronary heart disease mortality in Scotland between 1975 and 1994. Heart 1999, 8(4):380-386.

16. Central Bureau of Statistics: Central Bureau of Statistics. 2011 [http://www. cbssyr.org/index-EN.htm].

17. United Nations: Department of economics and social affairs. 2011. [http:// www.un.org/esa/population/]. Accessed on 27 January 2011.

18. Maziak W, Ward KD, Mzayek F, Rastam S, Bachir ME, Fouad MF, Hammal F, Asfar T, Mock J, Nuwayhid I, et al: Mapping the health and environmental situation in informal zones in Aleppo, Syria: report from the Aleppo household survey. Int Arch Occup Environ Health 2005, 78(7):547-558.

19. Schoen $\mathrm{R}$ : The geometric mean of the age-specific death rates as a summary index of mortality. Demography 1970, 7(3):317-324.

20. World Health Organization: Noncommunicable diseases. STEP wise surveillance. Syrian Arab Republic Report. 2003 [http://www.emro.who.int/ncd/pdf/ stepwise_syria.pdf].

21. Al Ali R, Rastam S, Fouad FM, Mzayek F, Maziak W: Modifiable cardiovascular risk factors among adults in Aleppo, Syria. Int J Public Health 2011, 56(6):653-62.

22. Hikita H, Sato A, Nozato T, Kawashima T, Takahashi Y, Kuwahara T, Takahashi A: Low coronary flow velocity and shear stress predict restenosis after sirolimus-eluting stent implantation. Scand Cardiovasc J 2009, 43(5):298-303.

23. Horie H, Takahashi M, Minai K, Izumi M, Takaoka A, Nozawa M, Yokohama H, Fujita T, Sakamoto T, Kito O, et al: Long-term beneficial effect of late reperfusion for acute anterior myocardial infarction with percutaneous transluminal coronary angioplasty. Circulation 1998, 98(22):2377-2382.

24. Topol EJ, Califf RM, Vandormael M, Grines CL, George BS, Sanz ML, Wall T, O'Brien M, Schwaiger M, Aguirre FV, et al: Circulation 1992, 85(6):2090-2099.

25. Randomised trial of intravenous streptokinase, oral aspirin, both, or neither among 17,187 cases of suspected acute myocardial infarction: ISIS-2. ISIS-2 (Second International Study of Infarct Survival) Collaborative Group. Lancet 1988, 2(8607):349-360.

26. Indications for ACE inhibitors in the early treatment of acute myocardial infarction: systematic overview of individual data from 100,000 patients in randomized trials. ACE Inhibitor Myocardial Infarction Collaborative Group. Circulation 1998, 97(22):2202-2212.

27. Collaborative meta-analysis of randomised trials of antiplatelet therapy for prevention of death, myocardial infarction, and stroke in high risk patients. BMJ 2002, 324((7329):71-86.

28. Al-Mallah MH, Tleyjeh IM, Abdel-Latif AA, Weaver WD: Angiotensinconverting enzyme inhibitors in coronary artery disease and preserved left ventricular systolic function: a systematic review and meta-analysis of randomized controlled trials. J Am Coll Cardiol 2006, 47(8):1576-1583.

29. Anand SS, Yusuf S: Oral anticoagulant therapy in patients with coronary artery disease: a meta-analysis. JAMA 1999, 282(21):2058-2067.

30. Boden WE, O'Rourke RA, Teo KK, Hartigan PM, Maron DJ, Kostuk WJ, Knudtson M, Dada M, Casperson P, Harris CL, et al: Optimal medical therapy with or without PCl for stable coronary disease. N Engl J Med 2007, 356(15):1503-1516

31. Boersma E, Harrington RA, Moliterno DJ, White H, Theroux P, Van de Werf F, de Torbal A, Armstrong PW, Wallentin LC, Wilcox RG, et al: Platelet glycoprotein Illb/llla inhibitors in acute coronary syndromes: a meta-analysis of all major randomised clinical trials. Lancet 2002, 359(9302):189-198.

32. Chen ZM, Jiang LX, Chen YP, Xie JX, Pan HC, Peto R, Collins R, Liu LS: Addition of clopidogrel to aspirin in 45,852 patients with acute myocardial infarction: randomised placebo-controlled trial. Lancet 2005, 366(9497):1607-1621.

33. Estess JM, Topol EJ: Fibrinolytic treatment for elderly patients with acute myocardial infarction. Heart 2002, 87(4):308-311. 
34. Flather MD, Yusuf S, Kober L, Pfeffer M, Hall A, Murray G, Torp-Pedersen C, Ball S, Pogue J, Moye L, et al: Long-term ACE-inhibitor therapy in patients with heart failure or left-ventricular dysfunction: a systematic overview of data from individual patients. ACE-Inhibitor Myocardial Infarction Collaborative Group. Lancet 2000, 355(9215):1575-1581.

35. Fox KA, Poole-Wilson P, Clayton TC, Henderson RA, Shaw TR, Wheatley DJ, Knight R, Pocock SJ: 5-year outcome of an interventional strategy in non-ST-elevation acute coronary syndrome: the British Heart Foundation RITA 3 randomised trial. Lancet 2005, 366(9489):914-920.

36. Freemantle N, Cleland J, Young P, Mason J, Harrison J: beta Blockade after myocardial infarction: systematic review and meta regression analysis. BMJ 1999, 318(7200):1730-1737.

37. Hulten E, Jackson JL, Douglas K, George S, Villines TC: The effect of early, intensive statin therapy on acute coronary syndrome: a meta-analysis of randomized controlled trials. Arch Intern Med 2006, 166(17):1814-1821.

38. Keeley EC, Boura JA, Grines CL: Primary angioplasty versus intravenous thrombolytic therapy for acute myocardial infarction: a quantitative review of 23 randomised trials. Lancet 2003, 361(9351):13-20.

39. Kjekshus J, Apetrei E, Barrios V, Bohm M, Cleland JG, Cornel JH, Dunselman P, Fonseca C, Goudev A, Grande P, et al: Rosuvastatin in older patients with systolic heart failure. N Engl J Med 2007, 357(22):2248-2261.

40. Law M, Wald N, Morris J: Lowering blood pressure to prevent myocardial infarction and stroke: a new preventive strategy. Health Technol Assess 2003, 7(31):1-94

41. Nadkarni VM, Larkin GL, Peberdy MA, Carey SM, Kaye W, Mancini ME, Nichol G, Lane-Truitt T, Potts J, Ornato JP, et al: First documented rhythm and clinical outcome from in-hospital cardiac arrest among children and adults. JAMA 2006, 295(1):50-57.

42. Oler A, Whooley MA, Oler J, Grady D: Adding heparin to aspirin reduces the incidence of myocardial infarction and death in patients with unstable angina. A meta-analysis. JAMA 1996, 276(10):811-815.

43. Pignone $M$, Phillips $C$, Mulrow $C$ : Use of lipid lowering drugs for primary prevention of coronary heart disease: meta-analysis of randomised trials. BMJ 2000, 321(7267):983-986.

44. Pitt B, Zannad F, Remme WJ, Cody R, Castaigne A, Perez A, Palensky J, Wittes J: The effect of spironolactone on morbidity and mortality in patients with severe heart failure. Randomized Aldactone Evaluation Study Investigators. N Engl J Med 1999, 341(10):709-717.

45. Sabatine MS, Cannon CP, Gibson CM, Lopez-Sendon JL, Montalescot G, Theroux P, Claeys MJ, Cools F, Hill KA, Skene AM, et al: Addition of clopidogrel to aspirin and fibrinolytic therapy for myocardial infarction with ST-segment elevation. N Engl J Med 2005, 352(12):1179-1189.

46. Shibata MC, Flather MD, Wang D: Systematic review of the impact of beta blockers on mortality and hospital admissions in heart failure. Eur J Heart Fail 2001, 3(3):351-357.

47. Tavazzi L, Maggioni AP, Marchioli R, Barlera S, Franzosi MG, Latini R, Lucci D, Nicolosi GL, Porcu M, Tognoni G: Effect of rosuvastatin in patients with chronic heart failure (the GISSI-HF trial): a randomised, double-blind, placebo-controlled trial. Lancet 2008, 372(9645):1231-1239.

48. Taylor RS, Brown A, Ebrahim S, Jolliffe J, Noorani H, Rees K, Skidmore B, Stone JA, Thompson DR, Oldridge N: Exercise-based rehabilitation for patients with coronary heart disease: systematic review and metaanalysis of randomized controlled trials. Am J Med 2004, 116(10):682-692.

49. Tunstall-Pedoe H, Bailey L, Chamberlain DA, Marsden AK, Ward ME, Zideman DA: Survey of 3765 cardiopulmonary resuscitations in British hospitals (the BRESUS Study): methods and overall results. BMJ 1992, 304 (6838):1347-1351.

50. Wilt TJ, Bloomfield HE, MacDonald R, Nelson D, Rutks I, Ho M, Larsen G, McCall A, Pineros S, Sales A: Effectiveness of statin therapy in adults with coronary heart disease. Arch Intern Med 2004, 164(13):1427-1436.

51. Yusuf S, Zhao F, Mehta SR, Chrolavicius S, Tognoni G, Fox KK: Effects of clopidogrel in addition to aspirin in patients with acute coronary syndromes without ST-segment elevation. N Engl J Med 2001, 345(7):494-502.

52. Yusuf S, Zucker D, Peduzzi P, Fisher LD, Takaro T, Kennedy JW, Davis K, Killip $T$, Passamani $E$, Norris $R$, et al: Effect of coronary artery bypass graft surgery on survival: overview of 10-year results from randomised trials by the Coronary Artery Bypass Graft Surgery Trialists Collaboration. Lancet 1994, 344(8922):563-570.

53. IMPACT Model: IMPACT Model Appendices. 2007 [http://www.liv.ac.uk/ PublicHealth/sc/bua/IMPACT_Model_\%20Appendices_May_2007.pdf].
54. Macintyre K, Capewell S, Stewart S, Chalmers JW, Boyd J, Finlayson A, Redpath A, Pell JP, McMurray JJ: Evidence of improving prognosis in heart failure: trends in case fatality in 66547 patients hospitalized between 1986 and 1995. Circulation 2000, 102(10):1126-1131.

55. Critchley JA, Capewell S: Substantial potential for reductions in coronary heart disease mortality in the UK through changes in risk factor levels. J Epidemiol Community Health 2003, 57(4):243-247.

56. Critchley JA, Capewell S, Unal B: Life-years gained from coronary heart disease mortality reduction in Scotland: prevention or treatment? J Clin Epidemiol 2003, 56(6):583-590.

57. Butler J, Arbogast PG, BeLue R, Daugherty J, Jain MK, Ray WA, Griffin MR: Outpatient adherence to beta-blocker therapy after acute myocardial infarction. J Am Coll Cardiol 2002, 40(9):1589-1595.

58. Briggs $A$, Sculpher $M$, Buxton $M$ : Uncertainty in the economic evaluation of health care technologies: the role of sensitivity analysis. Health Econ 1994, 3(2):95-104.

59. Gupta R: Burden of coronary heart disease in India. Indian Heart J 2005, 57(6):632-638

60. Musaiger AO: Overweight and obesity in eastern mediterranean region: prevalence and possible causes. J Obes 2011, 2011:407237.

61. State Planning commission of Syrian Arab Republic: The Tenth Five Years Planning 2006-2010. Chapet 20: Heath. 2006.

62. Albache N, Al Ali R, Rastam S, Fouad FM, Mzayek F, Maziak W: Epidemiology of Type 2 diabetes mellitus in Aleppo, Syria. J Diabetes 2010, 2(2):85-91

63. Unal B, Critchley JA, Capewell S: Explaining the decline in coronary heart disease mortality in England and Wales between 1981 and 2000. Circulation 2004, 109(9):1101-1107.

64. Beaglehole R, Bonita R, Alleyne G, Horton R: NCDs: celebrating success, moving forward. Lancet 2011, 378(9799):1283-1284.

doi:10.1186/1471-2458-12-754

Cite this article as: Rastam et al.: Explaining the increase in coronary heart disease mortality in Syria between 1996 and 2006. BMC Public Health 2012 12:754.

\section{Submit your next manuscript to BioMed Central and take full advantage of:}

- Convenient online submission

- Thorough peer review

- No space constraints or color figure charges

- Immediate publication on acceptance

- Inclusion in PubMed, CAS, Scopus and Google Scholar

- Research which is freely available for redistribution 